\title{
PROPAGATION OF A RARE ORNAMENTAL CLIMBER PLANT PORANA PANICULATA BY TISSUE CULTURE
}

\author{
A.M.Z. Sarhan ${ }^{*}$, F.M. Saadawy ${ }^{* *}$, Amaal A.M. Heikal ${ }^{*}$ and K.M. Abdel Kareem ${ }^{* *}$ \\ * Ornamental Horticulture Dept., Fac. Agric., Cairo Univ., Egypt. \\ ** Ornamental Plants \& Landscape Gardening Res. Dept., Hort. Res. Inst., Agric. Res. Cent., Egypt.
}

\begin{abstract}
This work was carried out in the Tissue Culture Laboratory, Horticulture Research Institute, Agricultural Research Center, Giza, Egypt during the period from 2015 to 2017, to investigate some factors affecting propagation of the rare ornamental climber Porana paniculata by tissue culture. Results could be briefed in the following: using clorox at $20 \%$ as a sterilant achieved the highest position in survival \% and the lowest one concerning contamination \%. The highest position was also occupied by clorox at $5 \%$ in relation to contamination \%. Exposing explants to clorox for either 15 or 20 min gave rise to the highest survival \%. Explants exposed to clorox at $20 \%$ for 15 min obtained the highest position in survival \%, the pre-lowest rank in contamination \% and the lowest one regarding mortality \%.

Using BAP at $0.60 \mathrm{ppm}$ gave rise to the highest position in lateral buds survival \%, regeneration capacity, culture efficiency, shoot number, shoot length and leaf number. Using 1/2 MS media induced

the $1^{\text {st }}$ position concerning lateral buds survival \%, regeneration capacity, culture efficiency, shoot number, shoot length and leaf number. Using BAP at $0.60 \mathrm{ppm}+1 / 2 \mathrm{MS}$ medium resulted in the highest records of lateral buds survival \%, regeneration capacity, culture efficiency, shoot number, shoot length and leaf number. BAP at $0.40 \mathrm{ppm}+1 / 2 \mathrm{MS}$ medium gave the 1 st rank of shoot number. Using BAP at $1 \mathrm{ppm}$ induced the $1^{\text {st }}$ position regarding shoot survival \%, shoot number, shoot length and leaf number. NAA at $0.1 \mathrm{ppm}$ resulted in the $1^{\text {st }}$ position regarding shoot survival \%, shoot number, shoot length and leaf number. BAP at $1 \mathrm{ppm}+\mathrm{NAA}$ at $0.1 \mathrm{ppm}$ recorded the $1^{\text {st }}$ position concerning shoot survival \%, shoot number, shoot length and leaf number.
\end{abstract}

Scientific J. Flowers \& Ornamental Plants, 4(3):259-272 (2017).

Received: 7/12/2017

Accepted: 16/12/2017

Key words: Porana paniculata, tissue culture, clorox, BAP, MS medium, NAA.

\section{INTRODUCTION}

Porana paniculata Roxburgh (syn. Poranopsis paniculata (Roxburgh) Roberty, Porana tomentosa Leschen. and Dinetus paniculatus (Roxburgh)) belongs to Family Convolvulaceae, native to northern India, Pakistan and Upper Burma, cultivated in Sri Lanka, Malaysia, Africa and the New World tropics, and known as Christmas vine, bridal bouquet, snow creeper, christ vine, snow creeper, snow - in - the - jungle or white corallita. It is evergreen, perennial strong twining climber or climbing vine, stems grayish pubescent herbaceous at the tips, woody at the base 4-9 m high. The stems are used for weaving baskets. Leaves dull green, ovate or heart-shaped, 4-9 cm long, cordate basally, obtuse, acute, acuminate or cuspidate apically, pubescent on both surfaces. From summer to early winter, this 
vine produces large laterals or terminal panicles or racemes that have fragrant blooms. Sepals linear, 1-1.5 mm long, densely tomentellous. Corolla white, funnelshaped, 5-6 mm long. Fruits indehiscent, ovoid-globose, 5-6 mm long, the outer 3 sepals enlarged and wing-l ike. Seeds ovoid, brown. Porana plants need full sun and regular irrigation without overwatering. Hardiness zone according to USDA is 11: above $4.5{ }^{\circ} \mathrm{C}$. Propagation by softwood cuttings or seeds in spring. Seed pods should be left to dry on plant. Properly cleaned seeds can be successfully stored. (InterNet Site 1-6, 2017).

Kumar et al. (2014) stated that phytochemical screening of whole plant of Porana paniculata revealed the presence of alkaloids, carbohydrates, saponins, tannins and flavonoids. They concluded that Porana paniculata whole plant possesses significant analgesic and anti inflammatory activities.

Daffalla et al. (2011) reported that plant growth regulators considerably affected the morphogenetic responses of Boscia senegalensis (Family Capparaceae). Both 2,4-D and TDZ tend to produce callus, whereas NAA improves the development of embryos to seedlings.

Moharami et al. (2014) cultured explants of Agastache foeniculum (Family Lamiaceae) on MS medium supplemented with various concentrations of BAP. They found that regeneration frequency was affected by BAP concentration. Wee et al. (2015) stated that propagation by tissue culture technology provides a better alternative than conventional propagation, as it ensures uniformity in production of sustainable plantlets with desirable traits.

\section{MATERIALS AND METHODS}

This work was carried out in the Tissue Culture Laboratory, Horticulture Research Institute, Agricultural Research Center, Giza, Egypt during the period from 2015 to 2017, to investigate some factors affecting the propagation of the rare ornamental climber Porana paniculata by tissue culture.

In the establishment stage, a few branches were collected from the sole Porana paniculata plant in Zohriya Garden. These branches were cut to small segments, washed under a current tap water, soaked and stirred in 3\% soap solution for $15 \mathrm{~min}$, rinsed under current tap water for $60 \mathrm{~min}$ before being rinsed three times under distilled water. Segments were then taken under hood in axenic conditions. Nodes bearing $1 \mathrm{~cm}$ long buds were excised and subjected to different sterilization treatments for the first experiment.

\section{The $1^{\text {st }}$ experiment (sterilization):}

The aforementioned explants were soaked in clorox solution at 5, 10 or $20 \%$ for 10,15 or $20 \mathrm{~min}$. These treatments were laid out in a factorial experiment in a completely randomized block design. Each treatment comprised 3 replicates, with 6 jars in each replicate. Explants were then rinsed three times, each for $30 \mathrm{~min}$, in a sterilized distilled water, before being inoculated individually in jars each containing $40 \mathrm{ml}$ of autoclaved (at $121{ }^{\circ} \mathrm{C}$ for 20 minutes under $1.05 \mathrm{~kg} / \mathrm{cm}^{2}$ pressure) full MS medium adjusted to $\mathrm{pH}$ 5.8. Each treatment comprised 3 replicates, with 6 jars in each replicate. These jars were kept in the incubation room at $25 / 20{ }^{\circ} \mathrm{C}$ (day/night) \pm 2 ${ }^{\circ} \mathrm{C}, 70 \%$ relative humidity. Two fluorescent tubes/shelf were installed at $30 \mathrm{~cm}$ above explants to provide light intensity of 22002400 lux at explant level. One month later the following data were recorded:

Survival $\%=$ percentage of explants that were alive, swollen and free of contamination.

Contamination $\%=$ percentage of explants that were contaminated whether alive or dead.

Mortality $\%=$ percentage of explants that were though free of contamination but dead. 
The $2^{\text {nd }}$ experiment (lateral buds establishment):

Lateral buds were excised from shoots obtained from Zohriya Garden and sterilized according to the best results of the $1^{\text {st }}$ experiment. These buds were then used as explants for the this experiment where the effect of 3 MS medium strengths (1/2, 3/4 and full MS medium) as the first factor, together with the effect of 6 BAP concentrations $(0.0,0.2,0.4,0.6,0.8$ and 1.0 $\mathrm{ppm})$ as the second factor, were studied in a factorial experiment with a completely randomized block design. Each treatment comprised 3 replicates, with 6 jars in each replicate. Data recorded one month later were:

$$
\text { Survival } \%=\frac{\begin{array}{c}
\text { Number of survived } \\
\text { explants }
\end{array}}{\begin{array}{c}
\text { Original inoculated } \\
\text { explants }
\end{array}} \times 100
$$

Number of explants$$
\begin{aligned}
& \begin{array}{l}
\text { Regeneration } \\
\text { capacity \% }
\end{array}=\frac{\text { that produced shoots }}{\text { Number of survived }} \\
& \text { explants }
\end{aligned} \times 100
$$$$
\begin{aligned}
& \text { Culture } \\
& \text { efficiency \% }
\end{aligned}=\frac{\begin{array}{l}
\text { Number of explants } \\
\text { that produced shoots }
\end{array}}{\begin{array}{l}
\text { Number of original } \\
\text { inoculated explants }
\end{array}} \times 100
$$

The $3^{\text {ed }}$ experiment (in vitro bud multiplication):

In vitro-produced buds taken from the $2^{\text {nd }}$ experiment were utilized in this stage. Three levels of NAA (0.0, 0.1 and $0.2 \mathrm{ppm})$ as the first factor combined with 4 concentrations of $\operatorname{BAP}(0,1,2$ and $3 \mathrm{ppm})$ as the second factor were arranged in a factorial experiment with a completely randomized block design. Each treatment comprised 3 replicates, with 6 jars in each replicate. Data recorded one month later were: survival \%, shoot number, shoot length and leaf number

For statistical test results of these experiments, analysis of variance was carried according to Snedecor and Cochran (1989).
The means were compared by Duncan's multiple range test at a probability level of 5\% (Duncan, 1955).

\section{RESULTS AND DISCUSSION}

\section{Experiment 1: Sterilization:}

Effect of clorox concentration and exposure time on survival \% (Table, 1 ):

Effect of clorox concentration: The effect of clorox concentration on survival \% was significant. Applying clorox at 20\% resulted in the highest survival $\%$ of explants, while using clorox at $5 \%$ gave rise to the lowest value in the same concern (45.50 and $17.72 \%$, respectively).

Effect of exposure time: The effect of exposure time on survival \% was significant. Exposing explants to the sterilant for 15 or 20 min induced higher survival \% than did the exposure for $10 \mathrm{~min}$ (38.10, 35.19 and $25.40 \%$, respectively).

Effect of the interaction between clorox concentration and exposure time on survival $\%$ : The effect of this interaction was found to be significant. The highest survival \% was obtained when clorox at $20 \%$ was used for $15 \mathrm{~min}$ (66.67\%). Records of explants treated with clorox at $10 \%$ for $20 \mathrm{~min}$ and those treated with the same material at $20 \%$ for $10 \mathrm{~min}$ occupied the second position (44.44 and 47.62\%, respectively). Explants subjected to clorox $5 \%$ for 5 min failed to survive at all.

Effect of clorox concentration and exposure time on contamination \% (Table, 2):

Effect of clorox concentration: The effect of clorox concentration on contamination $\%$ was significant. The highest contamination \% was obtained when clorox was used at 5\%, while the lowest one was a result of using the same material at $20 \%$ (65.61 and 23.02\%, respectively).

Effect of exposure time: The effect of exposure time on contamination \% was found to be significant. Applying clorox for only $10 \mathrm{~min}$ encouraged contamination to 
Table 1. Effect of clorox concentration and exposure time on survival \%.

\begin{tabular}{|c|c|c|c|c|}
\hline \multirow{2}{*}{ Clorox conc. (\%) } & \multicolumn{3}{|c|}{ Time (min) } & \multirow{2}{*}{ Mean } \\
\hline & 10 & 15 & 20 & \\
\hline 5 & $0.00 \mathrm{~g}$ & $14.29 \mathrm{f}$ & 38.89 bc & $17.72 \mathrm{C}$ \\
\hline 10 & 28.57 de & $33.33 \mathrm{~cd}$ & $44.44 \mathrm{~b}$ & $35.45 \mathrm{~B}$ \\
\hline 20 & $47.62 \mathrm{~b}$ & $66.67 \mathrm{a}$ & $22.22 \mathrm{ef}$ & $45.50 \mathrm{~A}$ \\
\hline Mean & $25.40 \mathrm{~B}^{\backslash}$ & $38.10 \mathrm{~A}^{\prime}$ & $35.19 \mathrm{~A}^{\prime}$ & \\
\hline
\end{tabular}

Means with the same letter are not significantly different according to Duncan's multiple range test (DMRT).

Table 2. Effect of clorox concentration and exposure time on contamination \%.

\begin{tabular}{|c|c|c|c|c|}
\hline \multirow{2}{*}{ Clorox conc. (\%) } & \multicolumn{3}{|c|}{ Time (min) } & \multirow{2}{*}{ Mean } \\
\hline & 10 & 15 & 20 & \\
\hline 5 & $85.71 \mathrm{a}$ & $66.67 \mathrm{~b}$ & $44.44 \mathrm{~cd}$ & $65.61 \mathrm{~A}$ \\
\hline 10 & 57.14 bc & $42.86 \mathrm{~cd}$ & $38.89 \mathrm{~d}$ & $46.30 \mathrm{~B}$ \\
\hline 20 & 33.33 de & 19.05 ef & $16.67 \mathrm{f}$ & $23.02 \mathrm{C}$ \\
\hline Mean & $58.73 \mathrm{~A}$ & $42.86 \mathrm{~B}$ & 33.33 C & \\
\hline
\end{tabular}

Means with the same letter are not significantly different according to Duncan's multiple range test (DMRT).

the utmost degree $(58.73 \%)$. On the other hand, extending exposure time to $20 \mathrm{~min}$ decreased contamination to $33.33 \%$.

Effect of the interaction between clorox concentration and exposure time: This effect was not significant. Despite this finding it could be noticed that using clorox at $5 \%$ for $10 \mathrm{~min}$ and at $20 \%$ for $20 \mathrm{~min}$ gave rise to the highest and the lowest contamination levels (85.71 and $16.67 \%$, respectively).

Effect of clorox concentration and exposure time on mortality \% (Table, 3 ):

Clorox concentration, exposure time and the interaction between these two factors significantly affected mortality \%.

Effect of clorox concentration: Applying clorox at $20 \%$ gave higher mortality \% compared to applying it at 5 or $10 \%$ (31.48, 16.67 and $18.25 \%$, respectively).

Effect of exposure time: Exposing explants to the sterilant effect for $20 \mathrm{~min}$ induced higher mortality \% compared to doing the same procedure for either 10 or 15 $\min (31.48,15.87$ and $19.05 \%$, respectively).

Effect of the interaction: Applying clorox at $20 \%$ for 20 min gave higher mortality \% (61.11\%) compared to all other treatments.

In this regard, Akbudak and Babaoglu (2005) showed that the most effective Epilobium parviflorum (Fam. Onagraceae) seed sterilizing solution was 25\% (v/v) sodium hypochlorite $(\mathrm{NaOCl})$. Wee et al. (2015) stated that high percentage of aseptic cultures were established from nodal, internodal and leaf explants of Sauropus androgynus sterilized with $70 \%$ ethanol for 1 min followed by $20 \%$ clorox for $20 \mathrm{~min}$.

\section{Experiment 2: Lateral buds establishment:}

Effect of BAP concentration and MS strength on lateral buds survival \% (Table, 4):

Effect of BAP concentration: The effect of BAP concentration was significant. The highest percentage was obtained when BAP at $0.60 \mathrm{ppm}$ was applied (43.21\%). The second position was the outcome of using BAP at $0.40,0.80$ and $1.00 \mathrm{ppm}$ (24.69, 25.93 and $23.46 \%$, respectively). Media free of BAP resulted in no survival at all.

Effect of MS strength: MS strength significantly affected this percentage. The highest value was observed when MS 
Table 3. Effect of clorox concentration and exposure time on mortality \%.

\begin{tabular}{|c|c|c|c|c|}
\hline \multirow{2}{*}{ Clorox conc. (\%) } & \multicolumn{3}{|c|}{ Time (min) } & \multirow{2}{*}{ Mean } \\
\hline & 10 & 15 & 20 & \\
\hline 5 & $14.29 \mathrm{~b}$ & $19.05 \mathrm{~b}$ & $16.67 \mathrm{~b}$ & $16.67 \mathrm{~B}$ \\
\hline 10 & $14.29 \mathrm{~b}$ & $23.81 \mathrm{~b}$ & $16.67 \mathrm{~b}$ & $18.25 \mathrm{~B}$ \\
\hline 20 & 19.05 b & $14.29 \mathrm{~b}$ & $61.11 \mathrm{a}$ & $31.48 \mathrm{~A}$ \\
\hline Mean & $15.87 \mathrm{~B} \backslash$ & $19.05 \mathrm{~B} \backslash$ & $31.48 \mathrm{~A} \backslash$ & \\
\hline
\end{tabular}

Means with the same letter are not significantly different according to Duncan's multiple range test (DMRT).

Table 4. Effect of BAP concentration and MS strength on lateral buds survival \%.

\begin{tabular}{ccccc}
\hline BAP conc. $(\mathbf{p p m})$ & $\mathbf{1 / 2} \mathbf{M S}$ & $\begin{array}{c}\text { MS strength } \\
\mathbf{3} / \mathbf{4} \mathbf{M S}\end{array}$ & full MS & Mean \\
\hline $\mathbf{0 . 0 0}$ & $0.00 \mathrm{f}$ & $0.00 \mathrm{f}$ & $0.00 \mathrm{f}$ & $0.00 \mathrm{D}$ \\
$\mathbf{0 . 2 0}$ & $37.04 \mathrm{c}$ & $0.00 \mathrm{f}$ & $0.00 \mathrm{f}$ & $12.35 \mathrm{C}$ \\
$\mathbf{0 . 4 0}$ & $51.85 \mathrm{~b}$ & $22.22 \mathrm{e}$ & $0.00 \mathrm{f}$ & $24.69 \mathrm{~B}$ \\
$\mathbf{0 . 6 0}$ & $74.07 \mathrm{a}$ & $29.63 \mathrm{~d}$ & $25.93 \mathrm{de}$ & $43.21 \mathrm{~A}$ \\
$\mathbf{0 . 8 0}$ & $51.85 \mathrm{~b}$ & $25.93 \mathrm{de}$ & $0.00 \mathrm{f}$ & $25.93 \mathrm{~B}$ \\
$\mathbf{1 . 0 0}$ & $48.15 \mathrm{~b}$ & $22.22 \mathrm{e}$ & $0.00 \mathrm{f}$ & $23.46 \mathrm{~B}$ \\
Mean & $43.83 \mathrm{~A}$ & $16.67 \mathrm{~B}$ & $4.32 \mathrm{C}^{\prime}$ & \\
\hline
\end{tabular}

Means with the same letter are not significantly different according to Duncan's multiple range test (DMRT).

medium at half strength was used, while the second rank resulted when using MS medium at 3/4 strength (43.83 and $16.67 \%$, respectively). The lowest record was observed when using MS medium at full strength (4.32\%).

Effect of the interaction between BAP concentration and MS strength on lateral buds survival \%: This interaction significantly affected lateral buds survival \%. Incorporating BAP at $0.60 \mathrm{ppm}$ in $1 / 2 \mathrm{MS}$ medium gave rise to the highest survival \% (74.07\%). The second position was a result of supplementing $1 / 2 \mathrm{MS}$ medium with BAP at $0.40,0.80$ or $1.00 \mathrm{ppm}$ (51.85, 51.85 and $48.15 \%$, respectively). No buds survived on media devoid of BAP. Survival failure occurred also when 3/4 MS medium was fortified with $0.20 \mathrm{ppm}$ BAP, or when full MS medium was supplemented with BAP at $0.20,0.40,0.80$ or $1.00 \mathrm{ppm}$.

Effect of BAP concentration and MS strength on regeneration capacity (Table, 5):

Effect of BAP concentration: BAP concentration significantly affected this character. The highest percentage was observed when BAP at $0.60 \mathrm{ppm}$ was applied (69.05\%). The second rank was the outcome of applying BAP at $0.40,0.80$ and $1.00 \mathrm{ppm}$ (33.33, 35.19 and 32.22\%, respectively). No buds survived on BAP-free media.

Effect of MS strength: MS strength significantly influenced this percentage. The highest record was obtained when 1/2 MS medium was adopted, while the second position resulted when using MS medium at 3/4 strength (45.08 and 38.89\%, respectively). The lowest value was observed when using full strength MS medium (7.41\%).

Effect of the interaction between BAP concentration and MS strength on regeneration capacity: The effect of this interaction was significant. The highest percentage was a result of incorporating BAP at $0.60 \mathrm{ppm}$ in MS medium at either $1 / 2$ or $3 / 4$ strength (84.92 and $77.78 \%$, respectively). Three quarters strength MS medium supplemented with BAP at 0.80 ppm induced the second position in the same 
A.M.Z. Sarhan et al.

Table 5. Effect of MS strength and BAP concentration on regeneration capacity.

\begin{tabular}{ccccc}
\hline BAP conc. (ppm) & $\mathbf{1 / 2} \mathbf{~ M S}$ & $\begin{array}{c}\text { MS strength } \\
\mathbf{3 / 4} \mathbf{M S}\end{array}$ & full MS & Mean \\
\hline $\mathbf{0 . 0 0}$ & $0.00 \mathrm{~d}$ & $0.00 \mathrm{~d}$ & $0.00 \mathrm{~d}$ & $0.00 \mathrm{D}$ \\
$\mathbf{0 . 2 0}$ & $38.89 \mathrm{c}$ & $0.00 \mathrm{~d}$ & $0.00 \mathrm{~d}$ & $12.96 \mathrm{C}$ \\
$\mathbf{0 . 4 0}$ & $50.00 \mathrm{bc}$ & $50.00 \mathrm{bc}$ & $0.00 \mathrm{~d}$ & $33.33 \mathrm{~B}$ \\
$\mathbf{0 . 6 0}$ & $84.92 \mathrm{a}$ & $77.78 \mathrm{a}$ & $44.44 \mathrm{bc}$ & $69.05 \mathrm{~A}$ \\
$\mathbf{0 . 8 0}$ & $50.00 \mathrm{bc}$ & $55.56 \mathrm{~b}$ & $0.00 \mathrm{~d}$ & $35.19 \mathrm{~B}$ \\
$\mathbf{1 . 0 0}$ & $46.67 \mathrm{bc}$ & $50.00 \mathrm{bc}$ & $0.00 \mathrm{~d}$ & $32.22 \mathrm{~B}$ \\
Mean & $45.08 \mathrm{~A}$ & $38.89 \mathrm{~B}$ & $7.41 \mathrm{C}^{\prime}$ & \\
\hline
\end{tabular}

Means with the same letter are not significantly different according to Duncan's multiple range test (DMRT).

question (55.56\%). No buds survived on media devoid of BAP. Survival failure occurred also when 3/4 MS medium was fortified with $0.20 \mathrm{ppm}$ BAP, or when full MS medium was supplemented with BAP at $0.20,0.40,0.80$ or $1.00 \mathrm{ppm}$.

Effect of BAP concentration and MS
strength on culture efficiency (Table, 6):

Effect of BAP concentration: The influence of BAP concentration was significant. The highest percentage was obtained when BAP at $0.60 \mathrm{ppm}$ was used (32.10\%). The second category was a result of applying BAP at $0.40,0.80$ and $1.00 \mathrm{ppm}$ (12.35, 13.58 and $11.11 \%$, respectively). No buds survived on media free of BAP.

Effect of MS strength: MS strength significantly affected this percentage. The highest record was obtained when 1/2MS medium was adopted, while the second position resulted when using MS medium at $3 / 4$ strength (25.31 and $9.88 \%$, respectively). The lowest value was observed when using full strength MS medium (1.85\%).

Effect of the interaction between BAP concentration and MS strength on culture efficiency: This effect was significant. The highest value occurred when 1/2 MS medium was supplemented with BAP at 0.60 ppm (62.96\%). The second position was occupied with the combinations of BAP at $0.40 \mathrm{ppm}+1 / 2 \mathrm{MS}, 0.80 \mathrm{ppm}+1 / 2 \mathrm{MS}$, BAP at $1.00 \mathrm{ppm}+1 / 2 \mathrm{MS}$ and BAP at 0.60 ppm + 3/4 MS (25.93, 25.93, 22.22 and $22.22 \%$, respectively). No buds survived on media devoid of BAP. Survival failure occurred also when 3/4 MS medium was fortified with $0.20 \mathrm{ppm}$ BAP, or when full MS medium was supplemented with BAP at $0.20,0.40,0.80$ or $1.00 \mathrm{ppm}$.

Effect of BAP concentration and MS strength on shoot number (Table, 7):

Effect of BAP concentration: The effect of BAP concentration was found to be significant. The highest number was obtained when BAP at $0.60 \mathrm{ppm}$ was used (1.33 shoots). The second rank resulted when applying BAP at $0.40,0.80$ and $1.00 \mathrm{ppm}$ (0.78, 0.67 and 0.67 shoots, respectively). No shoots emerged on media free of BAP.

Effect of MS strength: MS strength significantly affected shoot number. The highest record was observed when 1/2 MS medium was used, while the second position resulted when using MS medium at 3/4 strength (1.00 and 0.72 shoots, respectively). The lowest value was observed when using full strength MS medium (0.17 shoot).

Effect of the interaction between BAP concentration and MS strength on shoot number: This interaction significantly affected shoot number. The highest numbers were an outcome of combining BAP at 0.60 $\mathrm{ppm}+1 / 2 \mathrm{MS}$, BAP at $0.40 \mathrm{ppm}+1 / 2 \mathrm{MS}$ and BAP at $0.60 \mathrm{ppm}+3 / 4 \mathrm{MS}(1.67,1.33$ and 1.33 shoots, respectively). No shoots were obtained on media devoid of BAP. No shoots were found also when 3/4 MS medium was fortified with $0.20 \mathrm{ppm}$ BAP, 
Table 6. Effect of MS strength and BAP concentration on culture efficiency.

\begin{tabular}{ccccc}
\hline BAP conc. (ppm) & $\mathbf{1 / 2} \mathbf{~ M S}$ & $\begin{array}{c}\text { MS strength } \\
\mathbf{3 / 4} \mathbf{~ M S}\end{array}$ & full MS & Mean \\
\hline $\mathbf{0 . 0 0}$ & $0.00 \mathrm{~d}$ & $0.00 \mathrm{~d}$ & $0.00 \mathrm{~d}$ & $0.00 \mathrm{D}$ \\
$\mathbf{0 . 2 0}$ & $14.81 \mathrm{c}$ & $0.00 \mathrm{~d}$ & $0.00 \mathrm{~d}$ & $4.94 \mathrm{C}$ \\
$\mathbf{0 . 4 0}$ & $25.93 \mathrm{~b}$ & $11.11 \mathrm{c}$ & $0.00 \mathrm{~d}$ & $12.35 \mathrm{~B}$ \\
$\mathbf{0 . 6 0}$ & $62.96 \mathrm{a}$ & $22.22 \mathrm{~b}$ & $11.11 \mathrm{c}$ & $32.10 \mathrm{~A}$ \\
$\mathbf{0 . 8 0}$ & $25.93 \mathrm{~b}$ & $14.81 \mathrm{c}$ & $0.00 \mathrm{~d}$ & $13.58 \mathrm{~B}$ \\
$\mathbf{1 . 0 0}$ & $22.22 \mathrm{~b}$ & $11.11 \mathrm{c}$ & $0.00 \mathrm{~d}$ & $11.11 \mathrm{~B}$ \\
Mean & $25.31 \mathrm{~A}^{\prime}$ & $9.88 \mathrm{~B}$ & $1.85 \mathrm{C}^{\prime}$ & \\
\hline
\end{tabular}

Means with the same letter are not significantly different according to Duncan's multiple range test (DMRT).

Table 7. Effect of MS strength and BAP concentration on shoot number.

\begin{tabular}{ccccc}
\hline BAP conc. $(\mathbf{p p m})$ & $\mathbf{1 / 2} \mathbf{~ M S}$ & $\begin{array}{c}\text { MS strength } \\
\mathbf{3} / \mathbf{4} \mathbf{M S}\end{array}$ & full MS & Mean \\
\hline $\mathbf{0 . 0 0}$ & $0.00 \mathrm{c}$ & $0.00 \mathrm{c}$ & $0.00 \mathrm{c}$ & $0.00 \mathrm{D}$ \\
$\mathbf{0 . 2 0}$ & $1.00 \mathrm{~b}$ & $0.00 \mathrm{c}$ & $0.00 \mathrm{c}$ & $0.33 \mathrm{C}$ \\
$\mathbf{0 . 4 0}$ & $1.33 \mathrm{ab}$ & $1.00 \mathrm{~b}$ & $0.00 \mathrm{c}$ & $0.78 \mathrm{~B}$ \\
$\mathbf{0 . 6 0}$ & $1.67 \mathrm{a}$ & $1.33 \mathrm{ab}$ & $1.00 \mathrm{~b}$ & $1.33 \mathrm{~A}$ \\
$\mathbf{0 . 8 0}$ & $1.00 \mathrm{~b}$ & $1.00 \mathrm{~b}$ & $0.00 \mathrm{c}$ & $0.67 \mathrm{~B}$ \\
$\mathbf{1 . 0 0}$ & $1.00 \mathrm{~b}$ & $1.00 \mathrm{~b}$ & $0.00 \mathrm{c}$ & $0.67 \mathrm{~B}$ \\
Mean & $1.00 \mathrm{~A}$ & $0.72 \mathrm{~B}$ & $0.17 \mathrm{C}^{\prime}$ & \\
\hline
\end{tabular}

Means with the same letter are not significantly different according to Duncan's multiple range test (DMRT).

or when full MS medium was supplemented with BAP at $0.20,0.40,0.80$ or $1.00 \mathrm{ppm}$.

\section{Effect of BAP concentration and MS strength on shoot length (Table, 8):}

Effect of BAP concentration: The effect of BAP concentration on shoot length was significant. The longest shoots were obtained when BAP at $0.60 \mathrm{ppm}$ was applied, while the second rank was a result of using BAP at $0.80 \mathrm{ppm}$ (1.17 and $0.56 \mathrm{~cm}$, respectively). No shoots emerged on media free of BAP.

Effect of MS strength: MS strength significantly affected shoot length. The highest record was observed when 1/2 MS medium was used, while the second position resulted when using MS medium at 3/4 strength (0.89 and $0.38 \mathrm{~cm}$, respectively). The lowest value was observed when using full strength MS medium $(0.10 \mathrm{~cm})$.

Effect of the interaction between BAP concentration and MS strength on shoot length: This interaction significantly affected shoot length. The first and second positions were induced when 1/2 MS medium was fortified with BAP at either 0.60 or $0.80 \mathrm{ppm}$ (2.17 and $1.17 \mathrm{~cm}$, respectively). No shoots were obtained on media devoid of BAP. No shoots were found also when 3/4 MS medium was fortified with $0.20 \mathrm{ppm}$ BAP, or when full MS medium was supplemented with BAP at $0.20,0.40,0.80$ or $1.00 \mathrm{ppm}$.

Effect of BAP concentration and MS strength on leaf number (Table, 9):

Effect of BAP concentration: BAP concentration significantly affected this character. The greatest leaf number resulted when BAP was used at $0.6 \mathrm{ppm}$, followed with significant differences by numbers produced when BAP was applied at 0.40 , 0.80 and 1.00 ppm (1.78, 0.78, 0.89 and 0.78 leaves, respectively). No shoots emerged on media free of BAP.

Effect of MS strength: The highest value was obtained when 1/2 MS medium was 
A.M.Z. Sarhan et al.

Table 8. Effect of MS strength and BAP concentration on shoot length (cm).

\begin{tabular}{ccccc}
\hline BAP conc. (ppm) & $\mathbf{1 / 2} \mathbf{~ M S}$ & $\begin{array}{c}\text { MS strength } \\
\mathbf{3 / 4} \mathbf{M S}\end{array}$ & full MS & Mean \\
\hline $\mathbf{0 . 0 0}$ & $0.00 \mathrm{e}$ & $0.00 \mathrm{e}$ & $0.00 \mathrm{e}$ & $0.00 \mathrm{E}$ \\
$\mathbf{0 . 2 0}$ & $0.58 \mathrm{~cd}$ & $0.00 \mathrm{e}$ & $0.00 \mathrm{e}$ & $0.19 \mathrm{D}$ \\
$\mathbf{0 . 4 0}$ & $0.67 \mathrm{~cd}$ & $0.50 \mathrm{~d}$ & $0.00 \mathrm{e}$ & $0.39 \mathrm{C}$ \\
$\mathbf{0 . 6 0}$ & $2.17 \mathrm{a}$ & $0.75 \mathrm{c}$ & $0.58 \mathrm{~cd}$ & $1.17 \mathrm{~A}$ \\
$\mathbf{0 . 8 0}$ & $1.17 \mathrm{~b}$ & $0.50 \mathrm{~d}$ & $0.00 \mathrm{e}$ & $0.56 \mathrm{~B}$ \\
$\mathbf{1 . 0 0}$ & $0.75 \mathrm{c}$ & $0.50 \mathrm{~d}$ & $0.00 \mathrm{e}$ & $0.42 \mathrm{C}$ \\
Mean & $0.89 \mathrm{~A}$ & $0.38 \mathrm{~B}$ & $0.10 \mathrm{C}$ & \\
\hline
\end{tabular}

Means with the same letter are not significantly different according to Duncan's multiple range test (DMRT).

Table 9. Effect of MS strength and BAP concentration on leaf number.

\begin{tabular}{ccccc}
\hline BAP conc. $(\mathbf{p p m})$ & $\mathbf{1 / 2} \mathbf{~ M S}$ & $\begin{array}{c}\text { MS strength } \\
\text { 3/4 MS }\end{array}$ & full MS & Mean \\
\hline $\mathbf{0 . 0 0}$ & $0.00 \mathrm{~d}$ & $0.00 \mathrm{~d}$ & $0.00 \mathrm{~d}$ & $0.00 \mathrm{D}$ \\
$\mathbf{0 . 2 0}$ & $1.00 \mathrm{c}$ & $0.00 \mathrm{~d}$ & $0.00 \mathrm{~d}$ & $0.33 \mathrm{C}$ \\
$\mathbf{0 . 4 0}$ & $1.33 \mathrm{bc}$ & $1.00 \mathrm{c}$ & $0.00 \mathrm{~d}$ & $0.78 \mathrm{~B}$ \\
$\mathbf{0 . 6 0}$ & $2.67 \mathrm{a}$ & $1.67 \mathrm{~b}$ & $1.00 \mathrm{c}$ & $1.78 \mathrm{~A}$ \\
$\mathbf{0 . 8 0}$ & $1.67 \mathrm{~b}$ & $1.00 \mathrm{c}$ & $0.00 \mathrm{~d}$ & $0.89 \mathrm{~B}$ \\
$\mathbf{1 . 0 0}$ & $1.33 \mathrm{bc}$ & $1.00 \mathrm{c}$ & $0.00 \mathrm{~d}$ & $0.78 \mathrm{~B}$ \\
Mean & $1.33 \mathrm{~A}^{\backslash}$ & $0.78 \mathrm{~B}$ & $0.17 \mathrm{C}^{\prime}$ & \\
\hline
\end{tabular}

Means with the same letter are not significantly different according to Duncan's multiple range test (DMRT).

used, while the second category resulted when adopting MS medium at 3/4 strength (1.33 and 0.78 leaves, respectively). The lowest value was observed when using full strength MS medium (0.17 leaves).

Effect of the interaction between BAP concentration and MS strength on leaf number: The effect of this interaction was significant. Half strength MS medium augmented with BAP at $0.60 \mathrm{ppm}$ induced the highest number of leaves (2.67 leaves). The second position was occupied by the combinations of BAP at $0.40 \mathrm{ppm}+1 / 2 \mathrm{MS}$ medium, BAP at $0.80 \mathrm{ppm}+1 / 2 \mathrm{MS}$ medium, BAP at $1.00 \mathrm{ppm}+1 / 2 \mathrm{MS}$ medium and BAP at $0.60 \mathrm{ppm}+3 / 4 \mathrm{MS}$ medium (1.33, 1.67, 1.33 and 1.67 leaves, respectively). No shoots were obtained on media devoid of BAP. No shoots were found also when 3/4 MS medium was fortified with $0.20 \mathrm{ppm}$ BAP, or when full MS medium was supplemented with BAP at 0.20, 0.40, 0.80 or $1.00 \mathrm{ppm}$.

\section{Experiment 3: Effect of BAP and NAA concentrations on shoot multiplication:}

Shoot survival \% (Table, 10):

Effect of BAP concentration: This character was significantly influenced by BAP concentration. The highest percentage resulted when BAP was used at $1 \mathrm{ppm}$, followed in the second position by the outcome of applying BAP at either 2 or 3 ppm (65.43, 46.91 and 43.21\%, respectively). The lowest value was obtained when using BAP-free medium (18.52\%).

Effect of NAA concentration: NAA concentration significantly affected shoot survival \%. The highest value was obtained when NAA at $0.1 \mathrm{ppm}$ was used, followed in the second position by the result of using NAA at 0.2 ppm (54.63 and 41.67\%, respectively). The lowest record resulted in media free of NAA (34.26\%).

Effect of the interaction between BAP and NAA concentrations on shoot survival $\%$ : The effect of this interaction was 
Table 10. Effect of NAA and BAP concentrations on shoot survival \%.

\begin{tabular}{ccccc}
\hline BAP conc. (ppm) & \multicolumn{1}{c}{ NAA (ppm) } & $\mathbf{0 . 2}$ & Mean \\
\hline $\mathbf{0}$ & $\mathbf{0 . 0}$ & $\mathbf{0 . 1}$ & $25.93 \mathrm{~g}$ & $18.52 \mathrm{C}$ \\
$\mathbf{1}$ & $0.00 \mathrm{~h}$ & $29.63 \mathrm{fg}$ & $62.96 \mathrm{~b}$ & $65.43 \mathrm{~A}$ \\
$\mathbf{2}$ & $51.85 \mathrm{~cd}$ & $81.48 \mathrm{a}$ & $40.74 \mathrm{e}$ & $46.91 \mathrm{~B}$ \\
$\mathbf{3}$ & $44.44 \mathrm{de}$ & $55.56 \mathrm{bc}$ & $37.04 \mathrm{ef}$ & $43.21 \mathrm{~B}$ \\
Mean & $40.74 \mathrm{e}$ & $51.85 \mathrm{~cd}$ & $41.67 \mathrm{~B}$ & \\
\hline
\end{tabular}

Means with the same letter are not significantly different according to Duncan's multiple range test (DMRT).

significant. The highest shoot survival \% was the outcome of combining BAP at 1 ppm and NAA at $0.1 \mathrm{ppm}$, while the second position was the outcome of combining either BAP at 2 ppm and NAA at $0.1 \mathrm{ppm}$ or BAP at 1 ppm and NAA at $0.2 \mathrm{ppm}$ (81.48, 55.56 and $62.96 \%$, respectively). The lowest value belonged to the combination between BAP at $0.0 \mathrm{ppm}$ and NAA at $0.2 \mathrm{ppm}$ (25.93\%). Media free of both growth regulators failed to induce shoots at all.

\section{Shoot number (Table, 11):}

Effect of BAP concentration: BAP concentration significantly affected shoot number. The highest number was induced when using BAP at 1 ppm (1.67 shoots). The second category was obtained upon using BAP at either 2 or 3 ppm (1.11 and 1.00 shoots, respectively).

Effect of NAA concentration: NAA concentration significantly influenced this character. Applying NAA at $0.1 \mathrm{ppm}$ gave rise to higher number of shoots compared to using NAA at either 0.0 or $0.2 \mathrm{ppm}$ (1.42, 0.83 and 1.08 shoots, respectively).

Effect of the interaction between BAP and NAA concentrations: This interaction significantly affected shoot number. Applying BAP at $1 \mathrm{ppm}$ combined with NAA at $0.1 \mathrm{ppm}$ gave rise to higher number of (2.33 shoots) compared to all other combinations. Media free of both BAP and NAA failed to induce shoots at all.

\section{Shoot length (Table, 12):}

Effect of BAP concentration: Shoot length was significantly influenced by BAP concentration. The longest shoots were a result of using BAP at $1 \mathrm{ppm}$, followed in the second rank by shoots induced by BAP at $2 \mathrm{ppm}$ (2.04 and $1.29 \mathrm{~cm}$, respectively). The shortest ones were obtained on media free of BAP $(0.59 \mathrm{~cm})$.

Effect of NAA concentration: The effect of NAA concentration was significant. The longest shoots and the second order in this concern were obtained when NAA was used at 0.1 and $0.2 \mathrm{ppm}(1.72$ and $1.11 \mathrm{~cm}$, respectively). Media devoid of NAA induced the shortest shoots $(0.76 \mathrm{~cm})$.

Effect of the interaction between BAP and NAA concentrations: This interaction significantly affected shoot length. Combining both NAA at $0.1 \mathrm{ppm}$ and BAP at either 1 or $2 \mathrm{ppm}$ gave rise to the first and second positions (3.07 and $2.10 \mathrm{~cm}$, respectively). Media free of both BAP and NAA failed to induce shoots at all.

\section{Leaf number (Table, 13):}

Effect of BAP concentration: Leaf number was significantly affected by BAP concentration. The highest number was observed when BAP at $1 \mathrm{ppm}$ was applied (5.78 leaves). The second position was occupied by leaves obtained when BAP at either 2 or 3 ppm was used (2.56 and 2.11 leaves, respectively). The lowest record in this concern was a result of using BAP-free medium (1.33 leaves).

Effect of NAA concentration: NAA concentration significantly affected this character. NAA at 0.1 and $0.2 \mathrm{ppm}$ induced the first and second positions (3.50 and 3.00 leaves, respectively). Media free of NAA produced the lowest value (2.33 leaves). 
A.M.Z. Sarhan et al.

Table 11. Effect of NAA and BAP concentrations on shoot number.

\begin{tabular}{ccccc}
\hline BAP conc. (ppm) & $\mathbf{0 . 0}$ & NAA (ppm) & $\mathbf{0 . 2}$ & Mean \\
\hline $\mathbf{0}$ & $0.00 \mathrm{c}$ & $\mathbf{0 . 1}$ & $1.00 \mathrm{~b}$ & $0.67 \mathrm{C}$ \\
$\mathbf{1}$ & $1.33 \mathrm{~b}$ & $2.33 \mathrm{a}$ & $1.33 \mathrm{~b}$ & $1.67 \mathrm{~A}$ \\
$\mathbf{2}$ & $1.00 \mathrm{~b}$ & $1.33 \mathrm{~b}$ & $1.00 \mathrm{~b}$ & $1.11 \mathrm{~B}$ \\
$\mathbf{3}$ & $1.00 \mathrm{~b}$ & $1.00 \mathrm{~b}$ & $1.00 \mathrm{~b}$ & $1.00 \mathrm{~B}$ \\
Mean & $0.83 \mathrm{~B}$ & $1.42 \mathrm{~A}^{\backslash}$ & $1.08 \mathrm{~B}$ & \\
\hline
\end{tabular}

Means with the same letter are not significantly different according to Duncan's multiple range test (DMRT).

Table 12. Effect of NAA and BAP concentrations on shoot length (cm).

\begin{tabular}{ccccc}
\hline BAP conc. (ppm) & $\mathbf{0 . 0}$ & NAA (ppm) & $\mathbf{0 . 2}$ & Mean \\
\hline $\mathbf{0}$ & $0.00 \mathrm{f}$ & $0.77 \mathrm{e}$ & $1.00 \mathrm{e}$ & $0.59 \mathrm{D}$ \\
$\mathbf{1}$ & $1.30 \mathrm{~d}$ & $3.07 \mathrm{a}$ & $1.77 \mathrm{c}$ & $2.04 \mathrm{~A}$ \\
$\mathbf{2}$ & $0.92 \mathrm{e}$ & $2.10 \mathrm{~b}$ & $0.87 \mathrm{e}$ & $1.29 \mathrm{~B}$ \\
$\mathbf{3}$ & $0.83 \mathrm{e}$ & $0.93 \mathrm{e}$ & $0.80 \mathrm{e}$ & $0.86 \mathrm{C}$ \\
Mean & $0.76 \mathrm{C}^{\prime}$ & $1.72 \mathrm{~A}^{\backslash}$ & $1.11 \mathrm{~B}^{\backslash}$ & \\
\hline
\end{tabular}

Means with the same letter are not significantly different according to Duncan's multiple range test (DMRT).

Table 13. Effect of NAA and BAP concentrations on leaf number.

\begin{tabular}{ccccc}
\hline BAP conc. (ppm) & $\mathbf{0 . 0}$ & NAA (ppm) & $\mathbf{0 . 2}$ & Mean \\
\hline $\mathbf{0}$ & $0.00 \mathrm{e}$ & $2.00 \mathrm{~d}$ & $2.00 \mathrm{~d}$ & $1.33 \mathrm{C}$ \\
$\mathbf{1}$ & $4.33 \mathrm{c}$ & $7.33 \mathrm{a}$ & $5.67 \mathrm{~b}$ & $5.78 \mathrm{~A}$ \\
$\mathbf{2}$ & $2.67 \mathrm{~d}$ & $2.67 \mathrm{~d}$ & $2.33 \mathrm{~d}$ & $2.56 \mathrm{~B}$ \\
$\mathbf{3}$ & $2.33 \mathrm{~d}$ & $2.00 \mathrm{~d}$ & $2.00 \mathrm{~d}$ & $2.11 \mathrm{~B}$ \\
Mean & $2.33 \mathrm{C}^{\backslash}$ & $3.50 \mathrm{~A}^{\backslash}$ & $3.00 \mathrm{~B}$ & \\
\hline
\end{tabular}

Means with the same letter are not significantly different according to Duncan's multiple range test (DMRT).

Effect of the interaction between BAP and NAA concentrations: this interaction significantly influenced leaf number. The greatest and the second category values were obtained when BAP at 1 ppm was combined with NAA at either 0.1 or $0.2 \mathrm{ppm}$ (7.33 and 5.67 leaves, respectively). Media free of both BAP and NAA failed to induce shoots at all.

The previous results are comparable with those reported by a lot of workers. Yancheva (2002) postulated that MS medium with the addition of 1 ppm TDZ induced 100\% adventitious shoot formation of plum cultivar Stanley.

Bijelović et al. (2004) stated that in the presence of BAP numerous adventitious buds of Blackstonia perfoliata Family Gentianaceae, were formed, which were developed into shoots. The presence of IBA in media significantly decreased number of buds. Rahman et al. (2004) performed meristem culture of banana cV. BARI-I for shoot multiplication. They found that maximum shoot multiplication with highest shoot length was achieved on MS medium containing $4.0 \mathrm{mg} / \mathrm{l} \mathrm{BAP}+1.5 \mathrm{mg} / \mathrm{l}$ NAA. Banu and Bari (2007) noticed that the highest percentage of Ocimum sanctum shoot formation and highest average number of shoots were observed in $0.2 \mathrm{mg} / \mathrm{l} \mathrm{BAP}$ from shoot tip explants. Morais-Lino et al. (2008) found that it is possible to regenerate plants from cell suspensions of banana 
cultivar Terra using MS medium supplemented with $11.4 \mu \mathrm{M}$ (2 ppm) of IAA and $2.2 \mu \mathrm{M}(0.5 \mathrm{ppm})$ of BAP. Arias et al. (2010) established a method for regeneration of common bean (Phaseolus vulgaris). They remarked that MS medium supplemented with $5 \mathrm{mg} / \mathrm{lBAP}$ and 20 or $40 \mathrm{mg} / \mathrm{l}$ adenine sulphate resulted in the highest average of shoot formation.

Daffalla et al. (2011) reported that maximum number of shoots/explant of Boscia senegalensis (Family Capparaceae) was obtained on MS medium supplemented with $3.0 \mathrm{mg} / \mathrm{l}$ BA. Nada et al. (2011) declared that shoot buds of Begonia tuberhybrida were directly induced on leaf tissues from the cut ends and across the entire surface of both leaf and petiole segments. The highest frequency of shoot bud formation and the maximum number of shoots were achieved with modified MS media supplemented with $1.0 \mathrm{mg} / \mathrm{l} \mathrm{NAA}$ and $2.0 \mathrm{mg} / \mathrm{l} \mathrm{TDZ}$. In petioles, the maximum number of shoots was achieved with 0.5 $\mathrm{mg} / \mathrm{l} \mathrm{NAA}$ and $2.0 \mathrm{mg} / \mathrm{l} \mathrm{TDZ}$. Number of shoots produced in both explants was drastically reduced in the treatment with BAP alone or in combination with NAA and/or TDZ. In this regard, Ahmed and Anis (2012) stated that optimum shoot multiplication and elongation of Vitex trifolia was achieved when explants were subcultured on MS media containing a combination of $1.0 \quad 0.23$ ppm BAP and 0.1 ppm NAA. Salekjalali (2012) studied the effect of BAP in four levels $(0,1,2$ and 3 $\mathrm{mg} / \mathrm{l})$ and NAA in three levels (0, 0.1 and 1 $\mathrm{mg} / \mathrm{l})$ and their combinations on proliferation ability of damask rose (Rosa damascena). He reported that full-strength MS medium containing BAP (2 mg/l) and NAA (0.1 $\mathrm{mg} / \mathrm{l})$ had the best results for shoot proliferation of Rosa damascena. Sivparsad and Gubba (2012) declared that the highest percentage of shoot regeneration was obtained when apical shoot and axillary bud explants of sweet potato (Ipomoea batatas Lam.) cultivar Blesbok were cultivated on MS supplemented with $0.01 \mathrm{mg} / \mathrm{l} \mathrm{NAA}+1$ $\mathrm{mg} / \mathrm{l}$ BAP. Waoo et al. (2013) noticed that multiple shoots of Datura innoxia were induced in vitro from stem nodal and shot tip segments on MS medium containing BAP alone or in combination with NAA and kin. The highest number of shoots and shoot length were obtained with BAP, kin or NAA at $0.5 \mathrm{mg} / \mathrm{l}$.

Moharami et al. (2014) found that the highest shoot regeneration frequency of Agastache foeniculum (Family Lamiaceae) was recorded on media containing 1-2 ppm BAP + 0.2 ppm IAA. Gebeyehu (2015) investigated the effect of different concentrations of BAP and NAA on virus free plant regeneration and shoot multiplication of banana cV. Giant Cavendish. He found that $5.0 \mathrm{mg} / \mathrm{l} \mathrm{BAP} \mathrm{+}$ $0.5 \mathrm{mg} / \mathrm{l}$ NAA showed highest shoot proliferation. The longest shoots and the maximum number of leaves were produced with $5.0 \mathrm{mg} / \mathrm{l} \mathrm{BAP}+0.5 \mathrm{mg} / \mathrm{l}$ NAA. The second highest number of leaves was produced on medium supplemented with 5.0 $\mathrm{mg} / \mathrm{l} \mathrm{BAP}$ and $1.0 \mathrm{mg} / \mathrm{l}$ NAA. Paulos et al. (2015) investigated the effect of different concentration of BAP (0-10 mg/l), NAA (0-2 $\mathrm{mg} / \mathrm{l})$ on shoot multiplication of banana $\mathrm{cV}$. Grand Naine. They observed that media supplemented with $5 \mathrm{mg} / \mathrm{l}$ BAP resulted in the highest shoot number, shoot length and number of leaves. However, the combination of $5 \mathrm{mg} / \mathrm{l} \mathrm{BAP} \mathrm{+} \mathrm{NAA} 2.0 \mathrm{mg} / \mathrm{L}$ gave higher results. Shekhawat and Manokari (2015) reported that MS medium containing $0.5 \mathrm{mg} / \mathrm{l}$ BAP and $0.25 \mathrm{mg} / \mathrm{l}$ kin was optimum for induction of shoots from Nodal segments of Artemisia absinthium. The shoots were multiplied by repeated transfer of original explants and by subculturing of in vitro raised shoots on MS medium augmented with $1.0 \mathrm{mg} / 1$ each of BAP and KIN and $0.1 \mathrm{mg} / 1 \mathrm{NAA}$. Wee et al. (2015) stated that MS medium supplemented with $2.0 \mathrm{mg} / \mathrm{l} \mathrm{BAP}$ and $0.5 \mathrm{mg} / \mathrm{l} \mathrm{IAA}$ proved to be effective in inducing adventitious shoots from internodal, nodal and leaf explants of Sauropus androgynus. Quiroz et al. (2017) declared that the use of BAP in the culture media of Chilean strawberry (Fragaria chiloensis) increased the average 
rate of multiplication. However, plant height as well as number of leaves and roots, were higher in media without growth regulators.

\section{REFERENCES}

Ahmed, M.R. and Anis, M. (2012). Role of TDZ in the quick regeneration of multiple shoots from nodal explant of Vitex trifolia L., an important medicinal plant. Appl. Biochem. Biotechnol.,168(5):957-66.

Akbudak, M.A. and Babaoglu, M. (2005). Callus induction in small flowered willow herb (Epilobium parviflorum Schreb). J. Plant Biochem. and Biotech., 14(2):189-191.

Arias, A.M.G.; Valverde, J.M.; Fonseca, P.R. and Melara, M.V. (2010). In vitro plant regeneration system for common bean (Phaseolus vulgaris): effect of $\mathrm{N}^{6}$ benzylaminopurine and adenine sulphate. J. Biotech., 13(1):1-8.

Banu, L.A. and Bari, M.A. (2007). Protocol establishment for multiplication and regeneration of Ocimum sanctum Linn. an important medicinal plant with high religious value in Bangladesh. J. Plant Sci., 2:530-37.

Bijelović, A.; Rosić, N.; Miljuš-Djukić, J.; Ninković, S. and Grubišić, D. (2004). In vitro regeneration and transformation of Blackstonia perfoliata. Biologia Plantarum, 48(3):333-338.

Daffalla, H.H.; Abdellatef, E.; Elhadi, E.A. and Khalafalla, M.M. (2011). Effect of growth regulators on in vitro morphogenic response of Boscia senegalensis (Pers.) Lam. Poir. using mature zygotic embryos explants. Biotech. Res. Intl., 2011:1-8.

Duncan, D.B. (1955). Multiple range and multiple F tests, Biometrics, 11, 1-42.

Gebeyehu, A. (2015). Effects of different concentrations of BAP (6-benzyl amino purine) and NAA (naphthalene acetic acid) on banana (Musa spp.) cv. Giant
Cavendish shoot proliferation. Intl. J. Plant Sci. and Ecol., 1(2):36-43.

InterNet Site 1 (2017). https://ceb. wikipedia.org/wiki/Poranopsis_panicula.

InterNet Site 2 (2017). https://toptropicals. com/catalog/uid/poranopsis_pani culata. htm.

InterNet Site 3 (2017). https://www. greenplantswap.co.uk/plants/15404-pora na-paniculata

InterNet Site 4 (2017). http://www. efloras.org/florataxon.aspx? flora_id=5 \&taxon_id= 200018908

InterNet Site 5 (2017). http://www. efloras.org/florataxon.aspx? flora_id= 5\&taxon_id= 200018908

InterNet Site 6 (2017). https:// davesgarden.com/guides/pf/go/76887/

Kumar, A.; Reddy, J.R. and Vankadari, R.M.G. (2014). Evaluation of analgesic and anti inflammatory activities of Porana paniculata whole plant. Intl. J. Pharma. Bio. Sci., 5:413-421.

Moharami, L.; Hosseini, B.; Ravandi, E. and Jafari, M. (2014). Effects of plant growth regulators and explant types on in vitro direct plant regeneration of Agastache foeniculum, an important medicinal plant. In Vitro Cellular \& Develop. Biol. Plant, 50:707-711.

Morais-Lino, L.S.; Santos-Serejo, J.A. dos; Silva, S.de O.e.; Santana, J.R.F.de and Kobayashi, A.K. (2008). Cell suspension culture and plant regeneration of a Brazilian plantain, cultivar Terra. Pesquisa Agropecuária Brasileira, 43(10):1325-1330.

Nada, S.; Chennareddy, S.; Goldman, S.; Rudrabhatla, S.; Potlakayala, S.D.; Josekutty, P. and Deepkamal, K. (2011). Direct shoot bud differentiation and plantlet regeneration from leaf and petiole explants of Begonia tuberhybrida. HortScience, 46(5):759-764. 
Paulos, M.M.; Joshi, V.R. and Pawar, S.V. (2015). Effect of BAP and NAA on in vitro shoot establishment and proliferation of banana (Musa paradisiaca) cv. Grand naine. Intl. J. Sci. and Res. (IJSR), 4(5):318-323.

Quiroz, K.A.; Berríos, M.; Carrasco, B.; Retamales, J.B.; Caligari, P.D.S. and Garcia-Gonzales, R. (2017). Meristem culture and subsequent micropropagation of Chilean strawberry (Fragaria chiloensis (L.) Duch.). Biolo. Res., 50(20):1-11.

Rahman, M.Z; Nasiruddin, K.M.; Amin, M.A. and Islam, M.N. (2004). In vitro response and shoot multiplication of banana with BAP and NAA. Asian J. Plant Sci., 3(4):406-409

Salekjalali, M. (2012). Phloroglucinol, BAP and NAA enhance axillary shoot proliferation and other growth indicators in In vitro culture of damask rose (Rosa damascena Mill.). American-Eurasian J. Agric. \& Environ. Sci., 12(7):960-966.

Shekhawat, M.S. and Manokari, M. (2015). Efficient in vitro propagation by ex vitro rooting methods of Artemisia absinthium L., an ethnobotanically important plant. Chinese J. Biol., 2015:18.
Sivparsad, B.J. and Gubba, A. (2012). Development of an efficient plant regeneration protocol for sweet potato (Ipomoea batatas L.) cv. Blesbok. African J. Biotech., 11(84):14982-14987.

Snedecor, C.W. and Cochran, W.G. (1989). Two-way classification, analysis of variance Statistical Methods (8th Ed.). Iowa State Univ. Press Ames, Iowa, U.S.A. p. 254-268.

Waoo, A.A.; Khare, S. and Ganguli, S. (2013). In vitro propagation of Datura innoxia from nodal and shoot tip explants. World J. Environ. Engin., 1(1):1-4.

Wee, S.L.; Alderson, P.G. and Yap, W.S.P. (2015). Establishment of plantlet regeneration system from nodal, internodal and leaf explants of Sauropus androgynus (Sweet Shoot). Asian J. Biotech., 7:46-59.

Yancheva, S.D. (2002). Adventitious shoot formation from intact in vitro plants - An alternative approach towards genetic modification of plum (Prunus domestica L.). Biotechnology \& Biotechnological Equip., 16(2):62-66.

\footnotetext{
إكثار نبات الزينة المتسلق النادر بورانا بانيكيولاتا بواسطة زراعة الأنسجة

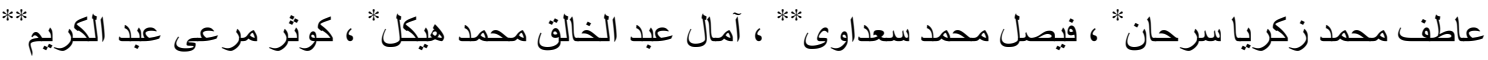
* قسم بساتين الزينة ، كلية الزر اعة ، جامعة القاتئ القاهرة، مصر.

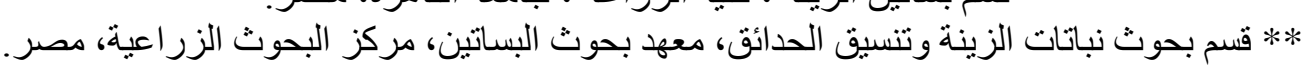

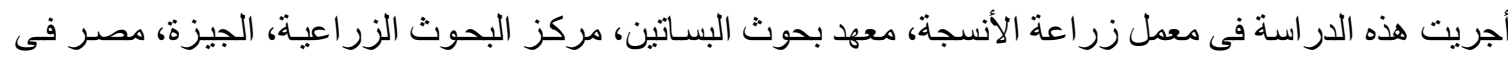

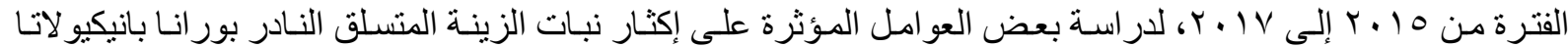

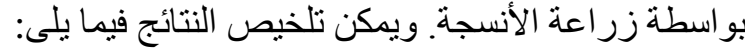

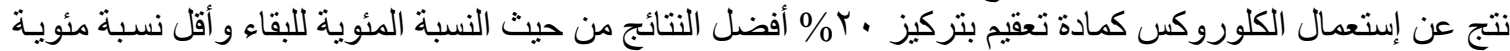

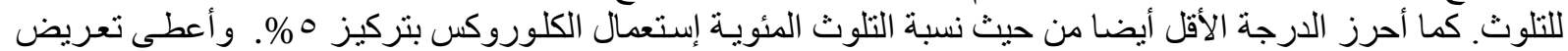

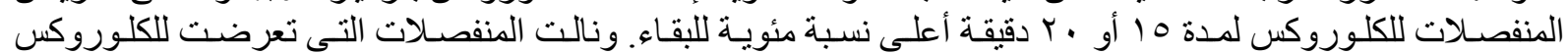

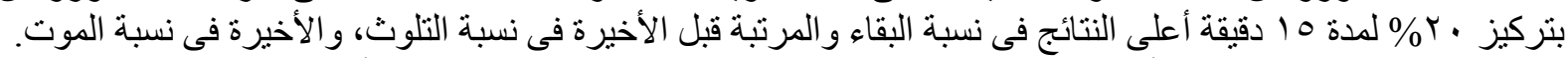

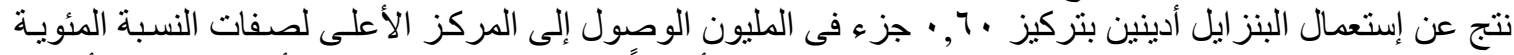

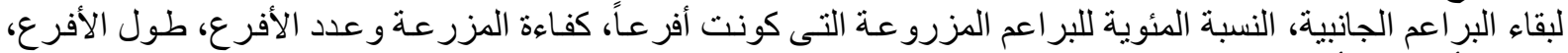

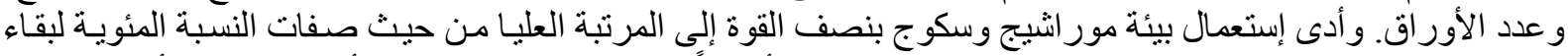

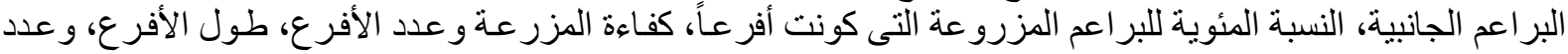




\section{A.M.Z. Sarhan et al.}

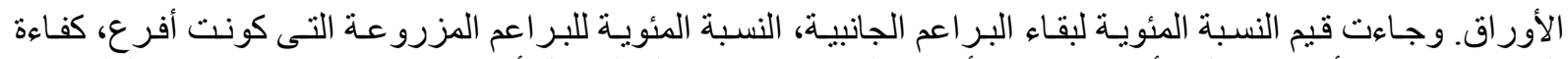

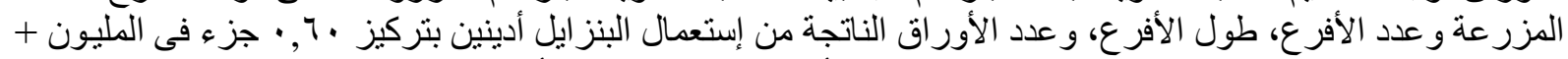

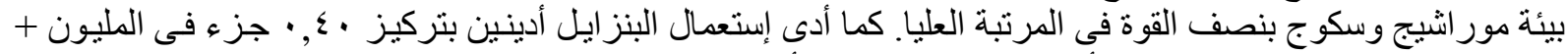

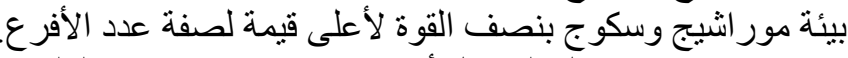

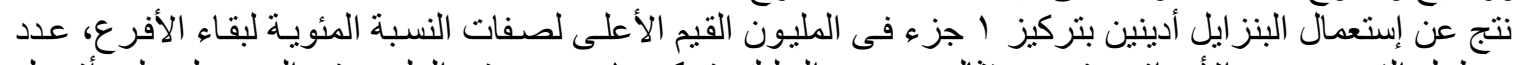

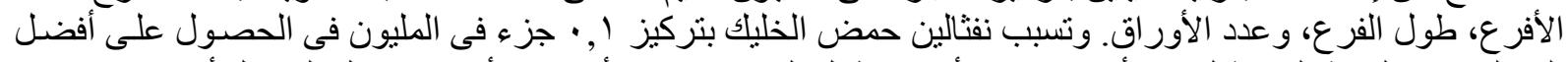

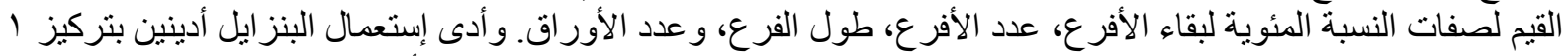

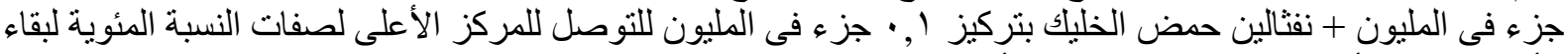
الأفرع ، عدد الأفرع، طول الفرل الفرع، وعدد الأور اق. 

